\title{
Çayda Besin Alımı, Gelișme, Enzim Aktivitesi ve Verimim Artırılması İçin Farklı Bitki Büyümesini Teșvik Edici Bakterilerin Birlikte Așılamasının Etkinliği
}

\author{
*Ramazan ÇAKMAKÇI ${ }^{1}$, Recep KOTAN², Ali ATASEVER ${ }^{3}$, Mustafa ERAT4 ${ }^{4}$, \\ Kubilay TÜRKYILMAZ ${ }^{5}$, Remzi SEKBAN ${ }^{5}$, Ayhan HAZNEDAR ${ }^{5}$
}

\author{
${ }^{1}$ Çanakkale Onsekiz Mart Üniversitesi, Ziraat Fakültesi, Tarla Bitkileri Bölümü, Çanakkale \\ ${ }^{2}$ Atatürk Üniversitesi, Ziraat Fakültesi Bitki Koruma Bölümü, Erzurum \\ ${ }^{3}$ Atatürk Üniversitesi, İspir Hamza Polat MYO, İspir, Erzurum \\ ${ }^{4}$ Atatürk Üniversitesi, Erzurum MYO, Teknik Programlar Bölümü, Kimya Programı, Erzurum \\ ${ }^{5}$ Atatürk Çay ve Bahçe Kültürleri Araștırma Enstitüsü, Rize
}

*Sorumlu yazar e-posta (Corresponding author e-mail): rcakmak@atauni.edu.tr

\begin{abstract}
Öz
Türkiye'de çay üretimi, kimyasal gübre uygulaması nedeniyle ciddi sorunlara neden olmaktadır. Bu nedenle, adeta tek tarımsal uğrașının çay yetiștiriciliği olduğu Doğu Karadeniz Bölgesi'nde, kimyasal gübre intiyacını azaltacak ve çay üretimini arttıracak yeni çevre dostu strateji ve ilave alternatif kaynakların değerlendirilmesi gerekmektedir. Bu çalıșma, mineral NPK gübrelemesi (80 kg/da kompoze \%25:5:10), bir ticari sıvı biyolojik gübre ve azot fikseri ve fosfat çözücü üçlü kombinasyon halinde bakteri esası iki farklı biyolojik gübre formülasyonunun (BFV1: Bacillus subtilis RC521 + Bacillus megaterium RC07 + Pseudomonas fluorescens RC77; BFVII: Bacillus subtilis RC11 + Bacillus megaterium RC07 + Pseudomonas putida RC06) asidik tarla koșullarında üç yıl süreyle çay gelișme, verim, enzim aktivitesi ve bitki besin element içeriği üzerine etkisinin belirlenmesi amacıyla yürütülmüștür. Deneme, beș uygulama ve her bir tekerrürde altı çay öbeği olacak șekilde üç tekerrürlü olarak tesadüf blokları deneme desenine göre düzenlenmiștir. Bakteri süspansiyonları bitki kök bölgesine enjekte edilerek uygulanmıștır. Biyolojik gübre formülasyonları ve mineral gübreleme Fener-3 Türk çay klonunda yaș ve kuru yaprak verimi, ikinci ve üçüncü yaprak alanı, yaprak makro ve mikro element, klorofil ve antioksidan içeriği, oksidatif, katalitik, hidrolitik ve antioksidan enzim aktivitesi dahil gelișmeyi teșvik etmiștir. Ayrıca, bakteri formülasyonu așılamaları, glutatyon redüktaz (GR), glutatyon S-transferaz (GST), glukoz 6-fosfat dehidrogenaz (G6PD), 6-fosfoglukonat dehidrogenaz (6PGD), polifenol oksidaz (PPO), peroksidaz (POD) ve alkol dehidrogenaz (ADH), 5-dehidroksișikimat redüktaz (DHSK) enzim aktivitesini değiștirebilmiștir. Bu araștırma bitki gelișmesini teșvik edici bakterilerle geliștirilen kararlı formülasyonların büyük önem tașıdığını ve sürdürülebilir çay tarımı için umut verici olduğunu göstermiștir.
\end{abstract}

Anahtar Kelimeler: Bitki gelișmesini teșvik edici rizobakteriler (PGPR), biyo-formülasyon, verim ve kalite, enzim aktivitesi, organik tarım

\section{Effectiveness of Co-inoculation of Different Plant Growth-Promoting Rhizobacteria for Improving Nutrients Uptake, Growth, Enzymes Activity and Yield of Tea}

\section{Abstract}

Tea production in Turkey causes serious problems due to application of chemical fertilizer. For this reason, it is necessary to evaluate the environment-friendly strategies and additional alternative resources that will reduce the need for chemical fertilizers and increase tea production in the Eastern Black Sea Region, where the only agricultural activity is tea growing. The objective of this study was to evaluate possible effects of mineral NPK fertilizer (800 kg ha-1 a compound fertilizer 25:5:10\%), one commercial liquid bio-fertilizer and ACC deaminasecontaining, $\mathrm{N}_{2}$-fixing, and P-solubilizing bacteria based bio-fertilizers in triple strains combinations (BFV1: $B$. subtilis RC521+B. megaterium RC07+P. fluorescens RC77; BFVII: $B$. subtilis RC11+B. megaterium RC07+P. putida RC06)) on the growth, yield, enzyme activities and nutrient uptake in tea under acidic field conditions in three years. The experiment was arranged as a completely randomized design with five treatments and three replicates (each having five tea bushes). Bio-fertilizer formulations and mineral fertilizer stimulated overall plant growth, including fresh and dry leaf yield, second and third leaf area, macro- and micro-nutrient concentrations chlorophyll and anthocyanin content in tea leaves, and activities of oxidative, catalytic, hydrolytic and antioxidative enzymes of Turkish tea clones Fener-3. In addition, inoculation with bacterial formulation also changed the activities of the enzyme like glutathione reductase (GR), glutathione S-transferase (GST), glucose-6-phosphate dehydrogenase (G6PD), 6-phosphogluconate dehydrogenase (6PGD), polyphenol oxidase (PPO), peroxidase (POD), urease, 5-dehydroshikimate reductase (DHSK), and alcohol dehydrogenases (ADH). This study clearly indicates that the development of stable formulation of plant growth promoting bacteria is of great importance and a promising approach to a sustainable tea agriculture.

Keywords: Plant growth promoting rhizobacteria, bio-formulation, yield and quality, enzyme activity, organic farming 


\section{Giriș}

ok yıllık olan çay bitkisi, uzun yılar 3 aynı toprakta kaldığından, sürekli aynı bitki besin maddelerini topraktan kaldırmakta, çay toprakları besin maddeleri yönünden fakirleștirmekte ve uygulanan gübreler toprak asitliğini arttırmaktadır. Toprakta eksilen $\mathrm{N}$ ve $\mathrm{P}$ miktarını karșılamak için yüksek oranda kimyasal gübre, özellikle azot kullanımı maliyetleri arttırmakta, önemli düzeyde yıkanmaya uğramakta, su ve çevre kirliliğine neden olmaktadır. Tarımsal kimyasalların așırı ve dengesiz kullanımı üretim maliyetlerini arttırmakta ve verimliliği düșürmektedir. Doğu Karadeniz Bölgesinde yoğun monokültür, tarımı nitrat kirliliğini ciddi boyutlarda arttırmakta, $P$ alım etkinliği giderek azalmakta, yıllardan beri tek yönlü ve yüksek dozda kimyasal gübreleme sonunda çay topraklarımızın fiziksel ve kimyasal yapısı giderek bozulmaktadır. Gereğinden fazla verilen azotlu gübre siyah çayda lif miktarının artmasına ve çay fabrikalarında lifin çaydan ayrıștırılması için daha fazla masraf yapılmasına neden olmaktadır. Çayın yapraklarından yararlanılması, taze sürgünlerinin vejetasyon periyodu içinde 3-4 kez kesilerek hasat edilmesi gibi nedenlerden ötürü, topraktan kaldırdığı azot miktarının yüksek olması çay için alternatif biyolojik gübre geliștirilmesini zorunlu kılmaktadır. Bu çalıșmada azot fikseri ve fosfat çözücü bakteri esaslı biyolojik gübre formülasyonlarının çay gelișme, verim ve enzim aktiviteleri üzerine etkileri araștırılmıștır.

\section{Materyal ve Yöntem}

Tarla denemesi, Çay İșletmeleri Genel Müdürlüğü Rize Atatürk Çay ve Bahçe Bitkileri Araștırma Enstitüsü'ne bağlı Hayrat Deneme İstasyonu'nda sekilerde 12 yașlı Fener-3 çay klonundan olușan çaylıkta kurulmuștur. $\mathrm{Bu}$ denemede sıvı tașıyıcıda geliștirilen 2 farklı bakteri kombinasyonu (BFV1: Bacillus subtilis RC521 + Bacillus megaterium RC07 + Pseudomonas fluorescens RC77; BFVII: Bacillus subtilis RC11 + Bacillus megaterium RC07 + Pseudomonas putida RC06) ve 1 biyolojik gübre, optimum NPK (80 kg/da kompoze \%25:5:10) ve kontrole kıyaslamalı olarak üç tekerrürlü ve her bir tekerrürde altı çay öbeği olacak șekilde kurulmuștur. Bakteri ve biyolojik gübre çay kök bölgesine enjekte edilmiștir.

Sıvı kombinasyon ve biyolojik gübre hazırlanırken sușlar saf kültür olarak Nutrient Agar (NA) ortamında $28^{\circ} \mathrm{C}$ 'de geliștirilmiș, taze kültürlerden bir öze dolusu alınarak 100 $\mathrm{mL}$ NB içerisine inokule edilmiș ve bir gece çalkalayıcıda (150 rpm/dk) inkübasyona bırakılmıștır. Daha sonra karıșım saf su ile seyreltilerek bakteri konsantrasyonu $10^{8}$ hücre/ $\mathrm{mL}$ olacak șekilde turbitimetre ile ayarlanmıștır. Karıșık formülasyonlarının hazırlanmasında, bakteri solüsyonu her bir bakterinin eșit miktar ve sayıda karıșımından olușturulmuștur. Biyoreaktörde tamamen organik maddelerden olușan ve buharla sterilizasyonu yapılan tașıyıcı sıvıya 1:10 oranında karıștırılarak așılama yapılmıștır. Çaylar Mayıs ayının ikinci haftasında (ilk sürgün), Temmuz ayının üçüncü haftasında (ikinci sürgün) ve Eylül ayının üçüncü haftasında (üçüncü sürgün) hasat edilmiștir.

Yaprak enzim aktivitesi spektrofotometrik olarak (UV-1208) belirlenmiștir. Glukoz 6-fosfat dehidrogenaz (G6PD) ve 6-fosfoglukonat dehidrogenaz (6PGD) aktivitesi Beutler (1984), Glutatyon redüktaz (GR) aktivitesi Carlberg ve Mannervik (1985), glutathione S-transferase (GST) aktivitesi ise Habig et al. (1974), protein içeriği ise Bradford metoduna (Bradford, 1976) göre belirlenmiștir. Polifenol oksidaz (PPO), peroksidaz (POD), üreaz, 5-dehidroksișikimat redüktaz (DHSK) ve alkol dehidrojenaz (ADH) aktivitesi sırasıyla Lee ve ark (1991), Mei et al. (2009), Nannipieri et al. (1980), Sanderson (1966) ve Hatanaka et al. (1974) tarafından ortaya konulan yöntemlere göre belirlenmiștir. Enzimatik aktiviteler $25^{\circ} \mathrm{C}$ ' de spektrofotometrik olarak ölçülmüștür (Shimadzu 1208 UV spektrofotometre). Çay yaprak klorofil miktarı tașınabilir klorofil metre (SPAD-502, Konica Minolta); antosiyanin içeriği tașınabilir antosiyanin ölçer (ACM-200 plus Anthocyanin Content Meter) ile ölçülmüștür. Yaprak numuneleri $68^{\circ} \mathrm{C}$ 'de 48 saat fırında kurutulmuș, $\mathrm{N}$ içeriği Kjeldahl yöntemi (Vapodest 10 Rapid Kjeldahl Distilasyon Ünitesi), yaprak makro ve mikro element içeriği İndüktif Coupled Plasma spektrofotometre ile (Perkin-Elmer, Optima 2100 DV, ICP/OES, Shelton, CT) belirlenmiștir. 


\section{Bulgular ve Tartıșma}

$\mathrm{Bu}$ denemede kullanılan biyolojik gübreler mineral gübrelenmeye eș değer yaprak verim artıșına neden olmuștur (Çizelge 1). Nitekim üç sürgün dönemi toplamına göre, kontrole kıyasla, denemenin ilk yllında dekara $80 \mathrm{~kg}$ olarak uygulanan kompoze gübreleme ile $\% 24.9$ ve $\% 24.8$ oranında artan yaș ve kuru yaprak ağırlığı, farklı biyolojik gübre kombinasyonları ile sırası ile \%18.1-27.0 ve \%13.7-23.8 oranında artmıștır. Benzer olarak yaș ve kuru yaprak verimi kompoze gübreleme ile ikinci yılda \%28.9 ve \%23.7, farklı biyolojik gübre kombinasyonlarında sırası ile \%13.2-34.1 ve \%14.2-25.7 oranında artmıștır. Önceki yıllara benzer olarak her üç sürgün dönemi ve toplamda yas ve yaprak verimi bakımından en etkin uygulama mineral NPK gübrelemesi ve BFV1 formülasyonu olmuștur. Kontrole kıyasla BFV1 ile kontrole kıyasla \%20.7 ve \%20 .9 ; dekara $80 \mathrm{~kg}$ olarak uygulanan kompoze gübreleme ile \%20.9 ve \%19.9 oranında artan yaș ve kuru yaprak verimi; BFVII formülasyonu ile \%15.0 ve \%15.6 oranında artmıștır.
Çay bitkilerindeki gram yaprak bașına enzim ünitesi olarak PPO aktivitesi NPK, BG ve BFVII, POD aktivitesi ise bașta BFVI olmak üzere NPK ve biyolojik gübre uygulaması; üreaz, $A D H$ ve DHSK redüktaz aktivitesi $B F V I$ bakteri formülasyonu așılaması ile kontrol ve kimyasal NPK gübre uygulamalarına kıyasla artmıș ve artıș oranları istatistiki bakımdan önemli bulunmuștur. PPO dıșındaki ölçümü yapılan enzimler bakımından en uygun sonucu BFV1 formülasyonu vermiștir (Çizelge 2).

İkinci yılda ölçülen yaprak GR ve GST aktivitesi bakteri formülasyonu ve gübre uygulamaları ile artmıș, G6PD enzim aktivitesi bașta BFVII formülü olmak üzere BFV1 ve NPK uygulamalarıla; 6PGD aktivitesi ise BFV1 ve BFV1I bakteri formülasyonu așılamalarıyla artmıș ve artıș oranları kontrole kıyasla önemli bulunmuștur. Yaprak GR, GST ve G6PD enzim aktivitesi bakımından BFVII bakteri formülü ve NPK, 6PGD enzim aktivitesi bakımından ise bakteri formülleri etkin olmuștur (Çizelge 3).

Çizelge 1. Tarla koșullarında Fener-3 klonunda farklı sürgün dönemlerinde mineral gübre ve farklı bakteri kombinasyonlarının çay yaprak verimi üzerine etkisi

Table 1. Effect of different combinations of bacteria and fertilizer applications on leaf yield at different harvesting periods of tea cv. Fener-3 in the field experiment during the 2013-2015 seasons.

\begin{tabular}{|c|c|c|c|c|c|c|c|c|}
\hline \multirow[b]{2}{*}{ Uygulama* } & \multicolumn{2}{|c|}{ Birinci sürgün } & \multicolumn{2}{|c|}{ İkinci sürgün } & \multicolumn{2}{|c|}{ Üçüncü sürgün } & \multicolumn{2}{|c|}{ Toplam } \\
\hline & $\begin{array}{c}\text { Yaș } \\
\text { yaprak } \\
\text { verimi (g/ } \\
\text { ocak) }\end{array}$ & $\begin{array}{c}\text { Kuru } \\
\text { yaprak } \\
\text { verimi (g/ } \\
\text { ocak) }\end{array}$ & $\begin{array}{c}\text { Yaș } \\
\text { yaprak } \\
\text { verimi (g/ } \\
\text { ocak) }\end{array}$ & $\begin{array}{c}\text { Kuru } \\
\text { yaprak } \\
\text { verimi (g/ } \\
\text { ocak) }\end{array}$ & $\begin{array}{c}\text { Yaș } \\
\text { yaprak } \\
\text { verimi (g/ } \\
\text { ocak) }\end{array}$ & $\begin{array}{c}\text { Kuru } \\
\text { yaprak } \\
\text { verimi (g/ } \\
\text { ocak) }\end{array}$ & $\begin{array}{c}\text { Yaș } \\
\text { yaprak } \\
\text { verimi (g/ } \\
\text { ocak) }\end{array}$ & $\begin{array}{c}\text { Kuru } \\
\text { yaprak } \\
\text { verimi (g/ } \\
\text { ocak) }\end{array}$ \\
\hline \multicolumn{9}{|c|}{ İlk yıl (2013) } \\
\hline Kontrol & $258 \mathrm{~b}$ & $128 \mathrm{~b}$ & $278 \mathrm{~b}$ & $141 \mathrm{~b}$ & $159 \mathrm{~b}$ & $79 \mathrm{~b}$ & $694 \mathrm{~b}$ & $347 \mathrm{~b}$ \\
\hline NPK & $322 \mathrm{a}$ & $154 \mathrm{a}$ & $347 \mathrm{a}$ & $169 a$ & $198 \mathrm{a}$ & $99 a$ & $867 \mathrm{a}$ & $422 \mathrm{a}$ \\
\hline BG & $304 \mathrm{a}$ & $141 \mathrm{a}$ & $329 \mathrm{a}$ & $161 \mathrm{a}$ & $188 \mathrm{a}$ & $94 \mathrm{a}$ & $820 \mathrm{a}$ & 395 a \\
\hline BFV1 & $327 \mathrm{a}$ & $157 \mathrm{a}$ & $354 \mathrm{a}$ & $173 \mathrm{a}$ & $202 \mathrm{a}$ & $101 \mathrm{a}$ & $882 \mathrm{a}$ & $430 \mathrm{a}$ \\
\hline BFVII & $310 \mathrm{a}$ & $149 \mathrm{a}$ & $336 \mathrm{a}$ & $164 \mathrm{a}$ & $192 \mathrm{a}$ & $96 \mathrm{a}$ & $837 \mathrm{a}$ & $409 \mathrm{a}$ \\
\hline \multicolumn{9}{|c|}{ İkinci yıl (2014) } \\
\hline Kontrol & $273.0 \mathrm{~d}$ & $130.0 \mathrm{c}$ & $259.0 \mathrm{~d}$ & $125.6 \mathrm{c}$ & $181.3 \mathrm{~d}$ & $87.9 \mathrm{c}$ & $713.4 \mathrm{~d}$ & $343.6 \mathrm{c}$ \\
\hline NPK & $358.3 a b$ & $166.0 \mathrm{a}$ & $329.5 \mathrm{ab}$ & $152.0 \mathrm{ab}$ & $231.6 \mathrm{~b}$ & $107.0 \mathrm{ab}$ & $919.5 \mathrm{ab}$ & $425.0 \mathrm{a}$ \\
\hline $\mathrm{BG}$ & $306.7 \mathrm{c}$ & $147.0 \mathrm{~b}$ & 294.5 c & $144.4 \mathrm{~b}$ & $206.1 \mathrm{c}$ & $101.1 \mathrm{~b}$ & $807.3 \mathrm{c}$ & $392.5 \mathrm{~b}$ \\
\hline BFV1 & $365.0 \mathrm{a}$ & $163.0 \mathrm{a}$ & $341.3 \mathrm{a}$ & $156.2 \mathrm{a}$ & $250.5 \mathrm{a}$ & $112.8 \mathrm{a}$ & $956.8 \mathrm{a}$ & $432.0 \mathrm{a}$ \\
\hline BFVII & $339.3 \mathrm{~b}$ & $159.3 \mathrm{a}$ & $327.9 \mathrm{~b}$ & $149.8 \mathrm{ab}$ & $229.5 \mathrm{~b}$ & $109.6 \mathrm{ab}$ & $896.8 \mathrm{~b}$ & $418.7 \mathrm{ab}$ \\
\hline \multicolumn{9}{|c|}{ Üçüncü yıl (2015) } \\
\hline Kontrol & $307 \mathrm{~d}$ & $137 \mathrm{~d}$ & $298 d$ & $138 \mathrm{c}$ & $194 \mathrm{c}$ & $91 \mathrm{c}$ & $799 \mathrm{c}$ & $365 \mathrm{c}$ \\
\hline NPK & 377 a & $171 \mathrm{a}$ & $357 \mathrm{a}$ & $160 a b$ & $232 a b$ & $107 \mathrm{~b}$ & 967 a & $438 \mathrm{a}$ \\
\hline BG & $329 c$ & $153 c$ & $320 \mathrm{c}$ & $152 \mathrm{~b}$ & $227 b$ & $105 \mathrm{~b}$ & $876 \mathrm{~b}$ & $409 \mathrm{~b}$ \\
\hline BFV1 & $357 \mathrm{ab}$ & $165 a b$ & $361 \mathrm{a}$ & $163 \mathrm{a}$ & $247 a$ & $114 \mathrm{a}$ & 965 a & $441 \mathrm{a}$ \\
\hline BFVII & $345 \mathrm{bc}$ & $156 \mathrm{bc}$ & $342 b$ & $159 \mathrm{ab}$ & $232 \mathrm{ab}$ & $107 \mathrm{~b}$ & $919 a b$ & $422 \mathrm{ab}$ \\
\hline
\end{tabular}

* Kontrol: Bakteri ve gübre uygulanmamıș; NPK: 80 kg/da kompoze \%25:5:10; BG: Ticari biyolojik gübre;

BFV1: Bacillus subtilis RC521+Bacillus megaterium RC07+Pseudomonas fluorescens RC77; BFVII: Bacillus subtilis RC11+Bacillus megaterium RC07+Pseudomonas putida RC06

${ }^{\star \star}$ Aynı harfle gösterilen ortalamalar arasındaki farklar kendi grubunda önemli $(p<0.05)$ değildir. 
Çizelge 2. Tarla koșullarında mineral gübre ve farklı bakteri kombinasyonlarının yaprak PPO, POD, üreaz, ADH ve DHSK enzim aktivitesi üzerine etkisi

Table 2. The effect of different combinations of bacteria and fertilizer applications on tea leaf $P P O, P O D$, urease, $A D H$ and DHSK enzymes activities under field experiment (First year)

\begin{tabular}{cccccc}
\hline \multirow{2}{*}{ Uygulama* $^{*}$} & \multicolumn{5}{c}{ Enzim aktivitesi (EU/g yaprak) $^{*}$} \\
\cline { 2 - 5 } & $\begin{array}{c}\text { Polifenol } \\
\text { oksidaz } \\
\text { (PPO) }\end{array}$ & $\begin{array}{c}\text { Peroksidaz } \\
\text { (POD) }\end{array}$ & Üreaz & $\begin{array}{c}\text { Alkol } \\
\text { dehidrogenaz } \\
\text { (ADH) }\end{array}$ & $\begin{array}{c}\text { 5-Dehidroksișikimat } \\
\text { redüktaz (DHSK) }\end{array}$ \\
\hline Kontrol & $7.38 \mathrm{~d}$ & $13.39 \mathrm{~d}$ & $1.03 \mathrm{c}$ & $1.41 \mathrm{bc}$ & $2.46 \mathrm{c}$ \\
NPK & $10.09 \mathrm{a}$ & $24.24 \mathrm{~b}$ & $1.06 \mathrm{c}$ & $1.36 \mathrm{bc}$ & $2.54 \mathrm{bc}$ \\
BG & $9.21 \mathrm{ab}$ & $20.56 \mathrm{c}$ & $1.23 \mathrm{bc}$ & $1.63 \mathrm{ab}$ & $3.15 \mathrm{ab}$ \\
BFV1 & $8.15 \mathrm{~cd}$ & $31.50 \mathrm{a}$ & $2.02 \mathrm{a}$ & $1.86 \mathrm{a}$ & $3.66 \mathrm{a}$ \\
BFVII & $9.01 \mathrm{bc}$ & $15.61 \mathrm{~d}$ & $1.46 \mathrm{~b}$ & $1.38 \mathrm{c}$ & $2.88 \mathrm{bc}$ \\
\hline
\end{tabular}

*Aynı harfle gösterilen ortalamalar arasındaki farklar kendi grubunda önemli $(p<0.05)$ değildir.

Üçüncü yıl sonuçlarına göre çay yapraklarında ölçülen GR, GST, G6PD ve 6PGD aktivitesi, biyolojik gübre dișındaki, bakteri formülasyonu ve gübre uygulamaları ile artmıș ve artıș oranları önemli bulunmuștur. Ölçülen her dört enzim aktivitesi bakımından BFVI bakteri formülü en etkin sonucu vermiștir. Araștırmanın ikinci yllında birinci sürgün döneminde alınan, klorofil içeriği ve yaprak alanı bütün uygulamalarla kontrole kıyasla önemli oranda artmıș, antosiyanin miktarı artıșı ise sadece NPK ve BFV1 formülasyonu așılamasındaönemlibulunmuștur. Üçüncüyılda ise yaprak klorofil içeriği, antosiyanin indeks değeri, ikinci ve üçüncü yaprak alanı bütün uygulamalarla kontrole kıyasla önemli oranda artmıștır. Ölçülen parametreler bakımından yeni test edilen biyolojik gübre olabilecek bakteri formülleri kimyasal gübrelemeye eș ve test edilen biyolojik gübreye kıyasla daha etkin bulunmuștur (Çizelge 3 ).

$\mathrm{Bu}$ araștırmada test edilen çoklu bitki geliștirme özelliklerine sahip üçlü bakteri formülasyonlarının Fener-3 Türk çay klonunda yaprak alanı, yaprak klorofil ve antosiyanin içeriği, yaprak makro ve mikro element içeriği, yaș ve kuru yaprak verimi, yaprak antioksidan, oksidatif pentoz fosfat yolu ve çay ișleme, tat ve aroması olușumunda önemli olabilecek enzim aktivitesi (GR, GST, G6PD, 6PGD PPO, $P O D$, üreaz, $A D H$ ve $D H S K$ ) dahil gelișmeyi teșvik edebildiği görülmüștür.

Denemenin ikinci ve üçüncü yılında çay yapraklarında ölçülen N, P, K, Mg, S ve Al içeriği kimyasal gübre ve biyolojik gübre olabilecek

Çizelge 3. Tarla koșullarında uygulamaların çay yaprak alanı, klorofil ve antosiyanin, GR, GST, G6PD ve 6PGD enzim aktivitesi üzerine etkisi

Table 3. Effects of The effect of different combinations of bacteria and fertilizer applications on the chlorophyll (SPAD) and anthocyanin (ACl) content, leaf area and enzymes activities (GR, GR, GST, G6PD ve $6 P G D$ ) in leaves of tea

\begin{tabular}{|c|c|c|c|c|c|c|c|c|}
\hline \multirow{2}{*}{ Uygulama } & \multirow{2}{*}{$\begin{array}{l}\text { Klorofil } \\
\text { (SPAD) } \\
\text { değeri* }^{*}\end{array}$} & \multirow{2}{*}{$\begin{array}{l}\text { Antosiyanin } \\
(\mathrm{ACl}) \text { değeri }\end{array}$} & \multirow{2}{*}{$\begin{array}{c}\text { İkinci } \\
\text { yaprak } \\
\text { alanı }\left(\mathrm{cm}^{2}\right)\end{array}$} & \multirow{2}{*}{$\begin{array}{c}\text { Üçüncü } \\
\text { yaprak } \\
\text { alanı }\left(\mathrm{cm}^{2}\right)\end{array}$} & \multicolumn{4}{|c|}{ Enzim aktivitesi EU/mg protein } \\
\hline & & & & & GR & GST & G6PD & 6PGD \\
\hline \multicolumn{9}{|c|}{ İkinci yıl (2014) } \\
\hline Kontrol & $70.9 \mathrm{c}$ & $26.9 \mathrm{~b}$ & $11.5 \mathrm{c}$ & $19.8 \mathrm{c}$ & $1.91 \mathrm{c}$ & $1.78 \mathrm{c}$ & $1.42 \mathrm{c}$ & $1.21 \mathrm{c}$ \\
\hline NPK & $77.6 \mathrm{a}$ & $29.7 \mathrm{a}$ & $14.7 \mathrm{a}$ & $24.9 \mathrm{a}$ & $2.36 \mathrm{a}$ & $2.06 \mathrm{a}$ & $1.87 \mathrm{~b}$ & $1.19 \mathrm{c}$ \\
\hline BG & $73.9 \mathrm{~b}$ & $27.8 \mathrm{ab}$ & $13.0 \mathrm{~b}$ & $22.4 \mathrm{~b}$ & $1.88 \mathrm{~b}$ & $1.91 \mathrm{~b}$ & $1.45 \mathrm{c}$ & $1.20 \mathrm{c}$ \\
\hline BFV1 & $77.4 \mathrm{a}$ & $29.4 \mathrm{a}$ & $15.2 \mathrm{a}$ & $25.8 \mathrm{a}$ & $2.18 \mathrm{~b}$ & $1.96 \mathrm{ab}$ & $1.84 \mathrm{~b}$ & $1.57 \mathrm{a}$ \\
\hline BFVII & $75.8 \mathrm{ab}$ & $28.8 \mathrm{ab}$ & $14.3 \mathrm{a}$ & $24.0 \mathrm{ab}$ & $2.33 \mathrm{a}$ & $2.03 \mathrm{a}$ & $1.99 \mathrm{a}$ & $1.48 \mathrm{~b}$ \\
\hline \multicolumn{9}{|c|}{ Üçüncü yıl (2015) } \\
\hline Kontrol & $72.18 \mathrm{c}$ & $26.21 \mathrm{c}$ & $12.62 \mathrm{c}$ & $21.07 \mathrm{c}$ & $1.90 \mathrm{c}$ & $1.74 \mathrm{~d}$ & $1.49 \mathrm{c}$ & $1.19 \mathrm{c}$ \\
\hline NPK & $82.83 a$ & $30.12 a b$ & $15.98 \mathrm{a}$ & $25.62 a b$ & $2.30 \mathrm{a}$ & $2.07 \mathrm{ab}$ & $1.84 \mathrm{a}$ & $1.38 \mathrm{ab}$ \\
\hline$B G$ & $80.48 \mathrm{~b}$ & 29.46 b & $14.18 \mathrm{~b}$ & $24.63 \mathrm{~b}$ & $2.04 \mathrm{bc}$ & $1.93 \mathrm{c}$ & $1.62 \mathrm{bc}$ & $1.28 \mathrm{bc}$ \\
\hline BFV1 & $84.76 \mathrm{a}$ & $31.72 \mathrm{a}$ & $16.34 \mathrm{a}$ & $26.71 \mathrm{a}$ & $2.26 \mathrm{a}$ & $2.12 \mathrm{a}$ & $1.85 \mathrm{a}$ & $1.48 \mathrm{a}$ \\
\hline BFVII & $83.79 \mathrm{a}$ & $30.16 \mathrm{ab}$ & $15.27 \mathrm{ab}$ & $25.07 \mathrm{~b}$ & $2.21 \mathrm{ab}$ & $1.99 \mathrm{bc}$ & $1.82 \mathrm{ab}$ & $1.39 \mathrm{ab}$ \\
\hline
\end{tabular}

${ }^{*}$ Aynı harfle gösterilen ortalamalar arasındaki farklar kendi grubunda önemli $(p<0.05)$ değildir. 
Çizelge 4. Tarla koșullarında farklı bakteri kombinasyonları ve mineral gübre uygulamalarının yaprak makro ve mikro element içeriğine etkisi

Table 4. Effect of different bacterial combinations and chemical fertilizer applications on the macro- and micro-nutrient concentrations in tea leaves

\begin{tabular}{|c|c|c|c|c|c|c|c|c|}
\hline \multirow{2}{*}{ Uygulama } & \multirow{2}{*}{$\stackrel{(\%)}{N}$} & \multicolumn{6}{|c|}{ Makro element içeriği $(\mathrm{g} / \mathrm{kg})^{\star}$} & \multirow{2}{*}{$\begin{array}{c}(\mathrm{mg} / \mathrm{kg}) \\
\mathrm{Na}\end{array}$} \\
\hline & & $\mathrm{P}$ & $\mathrm{K}$ & $\mathrm{Ca}$ & $\mathrm{Mg}$ & $S$ & $\mathrm{Al}$ & \\
\hline \multicolumn{9}{|c|}{ İkinci Yıl (2014) } \\
\hline Kontrol & $2.18 \mathrm{c}$ & $2.41 \mathrm{~d}$ & $16.3 d$ & $9.56 \mathrm{e}$ & $1.93 \mathrm{~d}$ & $2.77 \mathrm{~d}$ & $0.76 \mathrm{~d}$ & $45 \mathrm{~d}$ \\
\hline NPK & $2.99 \mathrm{a}$ & $3.92 \mathrm{~b}$ & $24.8 \mathrm{c}$ & $12.91 \mathrm{~d}$ & $2.67 \mathrm{c}$ & $3.18 \mathrm{c}$ & $2.34 a b$ & $56 \mathrm{~cd}$ \\
\hline$B G$ & $2.82 \mathrm{~b}$ & $3.12 \mathrm{c}$ & $22.4 \mathrm{c}$ & $15.28 \mathrm{c}$ & $2.54 \mathrm{c}$ & $3.67 \mathrm{~b}$ & $1.19 \mathrm{c}$ & $82 \mathrm{~b}$ \\
\hline BFV1 & $3.06 \mathrm{a}$ & $4.48 \mathrm{a}$ & $27.6 \mathrm{~b}$ & $20.80 \mathrm{a}$ & $3.47 \mathrm{a}$ & $3.99 \mathrm{a}$ & $2.13 \mathrm{~b}$ & $74 \mathrm{bc}$ \\
\hline BFVII & $2.95 \mathrm{a}$ & $4.06 \mathrm{~b}$ & $33.9 \mathrm{a}$ & $17.93 \mathrm{~b}$ & $2.91 \mathrm{~b}$ & $3.72 a b$ & $2.48 \mathrm{a}$ & $112 \mathrm{a}$ \\
\hline \multicolumn{9}{|c|}{ Üçüncü yıl (2015) } \\
\hline Kontrol & $2.38 \mathrm{c}$ & $2.93 \mathrm{c}$ & $20.2 \mathrm{c}$ & $12.19 \mathrm{~b}$ & $2.24 \mathrm{c}$ & $2.97 \mathrm{c}$ & $1.39 \mathrm{~b}$ & $59 \mathrm{~b}$ \\
\hline NPK & $2.98 a b$ & $3.90 a b$ & $26.0 \mathrm{ab}$ & $15.15 \mathrm{ab}$ & $2.81 a b$ & $3.52 \mathrm{~b}$ & $2.04 \mathrm{a}$ & $71 a b$ \\
\hline BG & $2.80 \mathrm{~b}$ & $3.43 \mathrm{bc}$ & $24.1 \mathrm{~b}$ & $15.26 \mathrm{ab}$ & $2.64 \mathrm{~b}$ & $3.53 \mathrm{~b}$ & $1.58 a b$ & $76 \mathrm{a}$ \\
\hline BFV1 & $3.04 \mathrm{a}$ & $4.09 a$ & $27.2 \mathrm{a}$ & $17.96 \mathrm{a}$ & $3.11 \mathrm{a}$ & $3.83 \mathrm{a}$ & $1.99 \mathrm{a}$ & $78 \mathrm{a}$ \\
\hline BFVII & $2.87 \mathrm{ab}$ & $3.77 \mathrm{ab}$ & $27.1 \mathrm{a}$ & $16.26 \mathrm{a}$ & $2.79 a b$ & $3.57 \mathrm{~b}$ & $2.02 \mathrm{a}$ & $83 a$ \\
\hline \multicolumn{9}{|c|}{ Mikro element (mg/kg) } \\
\hline Uygulama & $\mathrm{Fe}$ & $\mathrm{Cu}$ & $\mathrm{Mn}$ & $\mathrm{Zn}$ & $\mathrm{B}$ & Mo & $\mathrm{Ni}$ & $\mathrm{Pb}$ \\
\hline \multicolumn{9}{|c|}{ İkinci Yıl (2014) } \\
\hline Kontrol & $171 \mathrm{~d}$ & $17.7 \mathrm{~d}$ & $1772 \mathrm{~d}$ & $36.9 \mathrm{~d}$ & $23.3 \mathrm{~d}$ & $0.04 \mathrm{c}$ & $114 \mathrm{c}$ & $0.62 a b$ \\
\hline NPK & $204 c$ & $24.6 c$ & $2295 \mathrm{~b}$ & $52.4 \mathrm{bc}$ & $45.5 \mathrm{ab}$ & $0.59 a b$ & $253 \mathrm{a}$ & $0.81 \mathrm{a}$ \\
\hline BG & $252 \mathrm{~b}$ & $32.2 \mathrm{ab}$ & 2012 c & $45.8 \mathrm{~cd}$ & $35.8 \mathrm{bc}$ & $0.10 \mathrm{a}-\mathrm{c}$ & $252 \mathrm{a}$ & $0.47 \mathrm{~b}$ \\
\hline BFV1 & $361 \mathrm{a}$ & $31.6 a b$ & $2735 \mathrm{a}$ & $64.4 \mathrm{a}$ & $34.6 \mathrm{c}$ & $0.08 \mathrm{bc}$ & $189 \mathrm{~b}$ & $0.48 \mathrm{~b}$ \\
\hline BFVII & $251 \mathrm{~b}$ & $35.7 \mathrm{a}$ & $1878 \mathrm{~cd}$ & $60.2 \mathrm{ab}$ & $50.0 \mathrm{a}$ & $0.65 \mathrm{a}$ & $215 a b$ & $0.39 \mathrm{~b}$ \\
\hline \multicolumn{9}{|c|}{ Üçüncü yıl (2015) } \\
\hline Kontrol & $203 c$ & $23.4 \mathrm{~b}$ & $1855 \mathrm{~d}$ & $43.0 \mathrm{~d}$ & $32.1 \mathrm{c}$ & $0.19 \mathrm{~b}$ & $159 \mathrm{~b}$ & $0.53 \mathrm{a}$ \\
\hline NPK & $244 \mathrm{~b}$ & $28.3 \mathrm{a}$ & $2281 \mathrm{~b}$ & $54.3 \mathrm{~b}$ & $43.4 \mathrm{ab}$ & $0.40 \mathrm{a}$ & 229 a & $0.66 \mathrm{a}$ \\
\hline$B G$ & $249 \mathrm{~b}$ & $29.6 \mathrm{a}$ & 2092 c & $49.8 \mathrm{c}$ & $38.4 \mathrm{bc}$ & $0.23 \mathrm{~b}$ & $220 \mathrm{a}$ & $0.53 a$ \\
\hline BFV1 & $299 a$ & $31.0 \mathrm{a}$ & $2453 a$ & $58.9 \mathrm{a}$ & $40.3 a b$ & $0.31 a b$ & $211 a$ & $0.56 \mathrm{a}$ \\
\hline BFVII & $250 \mathrm{~b}$ & $31.0 \mathrm{a}$ & 2064 c & $55.0 \mathrm{~b}$ & $47.0 \mathrm{a}$ & $0.41 \mathrm{a}$ & $209 a$ & $0.50 \mathrm{a}$ \\
\hline
\end{tabular}

*Aynı harfle gösterilen ortalamalar arasındaki farklar kendi grubunda önemli $(p<0.05)$ değildir.

bakteri formülasyonları așılamalarılla kontrole kıyasla artmıș ve artıș oranları istatistiksel olarak önemli bulunmuștur (Çizelge 4).

Mineral gübreleme ve bakteri formülasyonları yaprak $\mathrm{Fe}, \mathrm{Cu}, \mathrm{Mn}, \mathrm{Zn}$ ve B içeriğini kontrole kıyasla artırmıștır. Çay yapraklarında ölçülen Mo içeriği ise NPK ve BFVII formülasyonu ile artmıștır. Yaprak makro ve mikro element analiz sonuçlarına göre bu deneme setinde test edilen bakteri formülasyonlarının çay beslenmesinde önemli olduğu ve besin element alımını artırdığı belirlenmiștir.

Önceki araștırmalarda Karadeniz Bölgesi çay rizosferinden izole edilerek (Çakmakçı ve ark., 2010) seçilen ve farklı çay klonlarında kullanılan tekli veya kombine biyolojik gübre formülasyonlarıın, çay gelișme ve verim parametrelerini, yaprak verimini, besin elementi içeriği ve enzim aktivitesini artırabileceği, organik yetiștiricilikte kullanılabileceği belirlenmiștir (Çakmakçı ve ark., 2011; 2012; 2016; Çakmakçı, 2016). Araștırma sonuçlarına göre, çay üretiminde biyolojik gübre uygulaması durumunda, daha az $\mathrm{N}$ ve $\mathrm{P}$ kimyasal gübresi kullanılarak geleneksel veya organik çay yetiștiricilerinin yüksek verim ve kaliteli üretimlerini devam ettirmeleri mümkün olabilecektir.

\section{Sonuç}

Çalıșma sonuçları çay ürün kalitesini artırma bakımından tașımaktadır. Çaydaki primer flavonellerin oksitlenmesi, tat ve rengin olușmasında önemli katkısı olan PPO; flavonellerin oksitlenmesinde, enzimlerin oksidasyon reaksiyonları, arıtma, aroma olușumu ve terpenlerin biyolojik dönüșümünde rolü olan POD; azot metabolizmasında rol 
alan üreaz; bazı alkollerin olușumu ve çayda aromanın gelișim ve olușumunda görev yapan $A D H$ ve polifenollerin biyosentezinde anahtar rol oynayan DHSK enzimleri aktivitesinin bakteri kullanılarak artııımıș olması çay üretiminde önemli olabileceği gibi bu konuda özgün yeni araștırmalara da ıșık tutacaktır.

Bu çalıșmada, çay tarımında kimyasal gübre gereksinimini azaltabilecek, bitki besleme ve kaliteyi teșvik edebilecek, yaprak makro ve mikro element içeriğini arttırabilecek, antioksidan ve çay kalite ve ișleme teknolojisinde önemli olabilecek enzim aktivitesini artıracak, çay

\section{Kaynaklar}

Beutler E., 1984. Red Cell Metabolism. Manual of Biochemical Methods. Third Edition, Grune Stratton, Inc. Orlando, FL 32887, London

Bradford M.M., 1976. A rapid and sensitive method for the quantitation of microgram quantities of protein utilizing the principle of protein-dye binding. Analytical Biochemistry $72: 248-254$

Carlberg I. ve Mannervik B., 1985. Glutathione Reductase. Methods Enzymol. Academic Press, Orlando, FL.113, 484-490

Çakmakçı R., 2016. Screening of multi-trait rhizobacteria for improving the growth, enzyme activities, and nutrient uptake of tea (Camellia sinensis). Communications in Soil Science and Plant Analysis, 47: 1680-1690. doi: 10.1080/00103624.2016.1206559

Çakmakçı R., Dönmez M.F., Ertürk Y., Erat M., Haznedar A. ve Sekban R 2010. Diversity and metabolic potential of culturable bacteria from the rhizosphere of Turkish tea grown in acidic soils. Plant and Soil, 332:299-318

Çakmakçı R., Ertürk Y., Atasever A., Ercişli S., Şentürk M., Erat M., Haznedar A. ve Sekban R., 2011. The use of plant growth promoting rhizobacteria for organic tea production in Turkey. Proceedings of Tea- Organic-Low Carbon International Symposium, 6-9 June, 2011, Guangyuan/China, 89-97

Çakmakçı R., Ertürk Y., Dönmez M.F., Erat M., Kutlu M., Sekban R. ve Haznedar A., 2012. Azot fikseri ve fosfat çözücü bakterilerin Muradiye 10 çay klonunda gelişme, verim ve besin alımı üzerine etkisi. Tarım Bilimleri Dergisi, 5(2):176-181

Çakmakçı R., Ertürk Y., Atasever A., Kotan R., Erat M., Varmazyari A., Türkyılmaz K., Sekban yetiștiriciliğinde kullanılabilecek, ticarileșme potansiyeli olan biyolojik gübre formülasyonları açıkolarak ortaya konulmuștur. Buaraștırmalarla geliștirilen ticarileșme potansiyeli olan biyolojik gübre formülleri organik çay yetiștiriciliğinde bitki besleme sorununu çözümüne önemli katkı yapacaktır.

\section{Teșekkür}

$\mathrm{Bu}$ araștırmayı TOVAG; 1120313 nolu proje kapsamında destekleyen TÜBITAK ve yetkililerine teșekkür ederiz.

R. ve Haznedar A., 2016. Development of Plant Growth-Promoting Bacteria Based Bio-formulations Using Liquid and Solid Carrier and Evaluation of their Influence on Growth Parameters and Enzyme Activity of Tea Plants. Tarla Bitkileri Merkez Araştırma Enstitüsü Dergisi, 25(2): 313-321

Habig W.H., Pabst M.J. ve Jakoby W.B., 1974. Glutathione S-transferase: The first enzymatic step in mercaptric acid formation. The Journal of Biological Chemistry, 249: 7130-7139

Hatanaka A., Kajiwara T., Tomohiro S. ve Yamashita H., 1974. Alcohol dehydrogenase from Thea sinensis seeds. Agricultural and Biological Chemistry, 38:1835-1844. doi: 10.1080/00021369.1974.10861430

Lee P.M., Lee K.H., Ismail M. ve Karim A., 1991. Biochemical studies of cocoa bean polyphenol oxidase. Journal of the Science of Food and Agriculture, 55: 251-260. doi: 10.1002/jsfa.2740550210

Mei X., Lin D.H., Xu Y., Wu Y.Y. ve Tu, Y.Y., 2009. Effects of phenanthrene on chemical composition and enzyme activity in fresh tea leaves. Food Chemistry, 115: 569-573

Nannipieri P., Ceccanti B., Cervelli S. ve Matarese E., 1980. Extraction of phosphatase, urease, protease, organic carbon, and nitrogen from soil. Soil Science Society of America Journal, 44: 1011-1016

Sanderson G.W., 1966. 5-dehydroshikimate reductase in the tea plant (Camellia sinensis L.) properties and distribution. Biochemical Journal, 98: 248-252. doi: 10.1042/ bj0980248 